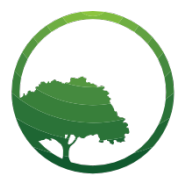

Research in Business \& Social Science

IJRBS VOL 8 NO 5 ISSN: 2147-4478

\title{
Competitiveness of strategic food commodities in Lampung Province, Indonesia
}

\author{
Wan Abbas Zakaria ${ }^{a}$, Teguh Endaryanto ${ }^{b}$, Lidyasari Mas Indah ${ }^{c}$, Lina Marlina ${ }^{d}$, \\ Indah Listiana ${ }^{e}$, \\ a,b,c,d,e Department of Agricultural Economics and Social Sciences College of Agriculture, University of Lampung, Bandar Lampung, Indonesia
}

\section{ARTICLE INFO}

\section{Article history:}

Received 28 July 19

Received in revs. form 12 August 19

Accepted 18 August 19

\section{Keywords:}

Lampung

Competitiveness

Strategic food commodities

JEL Classification:

F31

O10

\begin{abstract}
A B S T R A C T
Food commodities play an important role in income increase of people, job opportunities, and regional and national development. Competitiveness of food commodities needs for community welfare increase and national food security and sovereignty. The aims of this research were: (1) to analysis of competitiveness of strategic food commodities in Lampung Province, (2) to analyze the impact of changes of input and output prices against of strategic food commodities in Lampung Province, and (3) to know the policy of suitable minimum prices of strategic food commodities in Lampung Province. This research conducted in Lampung Province from September 2013 to September 2014. The regencies as a sample selected by purposive sampling were Middle Lampung, North Lampung, South Lampung, and East Lampung. The determination of the farmers used stratified simple random sampling. The sample in this study was 120 respondents. The results showed that the farming of strategic food commodities (paddy and corn) had PCR and DCR value less than one point. Strategic food commodities had lesser value due to an increase in fertilizer price and a decline in output prices. The competitiveness of strategic food commodities in Lampung Province was sensitive to output prices decrease. The policy of the minimum price of paddy at least two times greater than the price of corn.
\end{abstract}

\section{Introduction}

Agricultural development intends to achieve competitive and sustainable industrial agriculture based on local resources, to expand food security and nutrition, to improve food diversification, to increase value, competitiveness, and export, as well as to increase welfare and income. To achieve those goals, Ministry of Agriculture has set prime target, i.e.: achieve rice self and sustainable sufficiency in production, improvement food diversification, increase added value and export, and improvement of farmers welfare (KementerianPertanian, 2009).

Although Lampung Province is the center of rice and corn production, some areas in the region still experiencing problems that could affect the availability of food. Farm land for food commodities has decreased in some areas. The decrease is due to land conversion, from food commodities into plantation crops such as rubber, oil palm and cocoa, which is done by farmers. In this paper, data were obtained from the Department of Agriculture and Horticulture (PTPH) Lampung, agricultural land conversion has reached 38.31 percent of total the land area of 447 thousand hectares (ha). The decreased of farm land affect the production of important agricultural commodities in Lampung, namely rice and maize. In addition, the attacks of various diseases causethe decrease of quality and quantity of crops resulting in low prices. Low selling prices and high production costs caused low profits.

* Corresponding author. ORCID ID: 0000-0001-7916-1891

Peer review under responsibility of Bussecon International Academy.

(C) 2019 Bussecon International. Hosting by SSBFNET- Center for Strategic Studies in Business \& Finance. All rights reserved.

https://doi.org/10.20525/ijrbs.v8i5.477 
This study aims to: (i) analyze the competitiveness of strategic food commodities in Lampung Province, (ii) analyze the impact of changes in input and output prices on the competitiveness of strategic food commodities in Lampung Province, and (iii) determine minimum pricing policy that is suitable for strategic food commodities in Lampung Province.

\section{Research and Methodology}

The importance of the agricultural sector to the national economic can be seen, one of which, from the amount of Indonesia's gross domestic income derived from agriculture sector, which is known as second-biggest sector after food processing sector. The contribution of agricultural sector on gross domestic income tend to be decreased from $15.28 \%$ at the end of 2010 to $14.44 \%$ at the end of 2012. Food comodity becomes a prime sub-sector that is very important. Food commodity is very crucial and potential because food commodity is necessary for human life. There are several main food commodities, i.e. rice and corn. Rice is Indonesia main staple food, while corn is important for feed industry in addition to staple food. Production target of food crops in Indonesia in 20102014 is shown in Table 1.

Table 1: Production target of food crops in Indonesia in 2010-2014

\begin{tabular}{lllllll}
\hline No & Commodities & \multicolumn{2}{l}{ Year } & & & \\
& & & & \\
& & $\mathbf{2 0 1 0}$ & $\mathbf{2 0 1 1}$ & $\mathbf{2 0 1 2}$ & $\mathbf{2 0 1 3}$ & $\mathbf{2 0 1 4}$ \\
\cline { 3 - 7 } & & $\mathbf{( 0 0 0}$ ton) & & & & \\
\hline $\mathbf{1}$ & Rice & 66.680 & 68.800 & 71.000 & 73.300 & 75.700 \\
\hline $\mathbf{2}$ & Corn & 19.800 & 22.000 & 24.000 & 26.000 & 29.000 \\
\hline $\mathbf{3}$ & Soy Bean & 1.300 & 1.560 & 1.900 & 2.250 & 2.700 \\
\hline $\mathbf{4}$ & Cassava & 22.248 & 22.400 & 25.000 & 26.300 & 27.600 \\
\hline $\mathbf{5}$ & Sweet potato & 2.000 & 2.150 & 2.300 & 2.450 & 2.600
\end{tabular}

Source : Agriculture Ministry, 2009

Lampung Province is one of the centers of production of rice and corn in Indonesia. Lampung Province is seventh largest rice production center and third largest corn production center in Indonesia. As food production center in Indonesia, Lampung province should be able to increase production and productivity of farming, in order to contribute to the fulfillment of target production of rice and maize that is established by national government, to meet the needs in local and national markets (Zakaria, 2000). Increased competitiveness needs to be placed on the conception of the increase in welfare which is measured from the increased of farm productivity. Increased productivity can be done by allocating factors of production efficiently to produce maximum production or to reduce production costs. In addition, the government has also established a variety of policy to help farmers to increase productivity as well as comparative and competitive advantages of farming, such as input subsidies and regional minimum price (Suryana, 1980; Sambodo, Ahmad, and Purwanto, 2007).

The research was conducted in Lampung Province. Research location was determined purposively based on survey result. Based on the survey, four regency was determined as the center of important food commodities in Lampung Province, namely, Central Lampung, North Lampung, SouthLampung and East Lampung. Sampling method was stratified random sampling assuming homogeneous groups'population. Research method was survey method. The data used in this study were primary data and secondary data. The primary data obtained through direct interviews with farmer households respondents. Secondary data were obtained from the department or agency related to the study and previous reports. Competitiveness analysis performed using Police Analysis Matrix (PAM). PAM is used to calculate the revenues, expenses, and profits in private and social rates, as shown in Table 2.

Table 2: Policy Analysis Matrix (PAM)

\begin{tabular}{llllll}
\hline No & Description & Revenue & Cost & Profit \\
\cline { 3 - 5 } & & Input Tradeable & Input Nontradeable & \\
\hline $\mathbf{1}$ & Private Price & $\mathrm{A}$ & $\mathrm{B}$ & $\mathrm{C}$ & $\mathrm{D}$ \\
\hline $\mathbf{2}$ & Social Price & $\mathrm{E}$ & $\mathrm{F}$ & $\mathrm{G}$ & $\mathrm{H}$ \\
\hline $\mathbf{3}$ & Policy Impact & $\mathrm{I}$ & $\mathrm{J}$ & $\mathrm{K}$ & $\mathrm{L}$ \\
\hline
\end{tabular}

Source: Pearson, et.al.,2005 


\section{Description:}

Financial Profit

$=\mathrm{A}-(\mathrm{B}+\mathrm{C})$

Economic Profit

$$
=\mathrm{E}-(\mathrm{F}+\mathrm{G})
$$

Transfer Output (OT)

(I) $\quad$ A-E

Transfer InputTradeable (IT)

(J)

Transfer InputNontradeable (FT)$$
=\mathrm{B}-\mathrm{F}
$$

Net Transfer (NT)

$$
=\mathrm{C}-\mathrm{G}
$$

Private Cost Ratio (PCR)

Domestic Resources Cost Ratio (DRC)

Nominal Protection Coeficient of Output (NPCO)

Nominal Protection Coeficient of Input(NPCI)

Efective Protection Coeficient (EPC)

Profit Coeficient (PC)

Subsidi Ratio to Produsen (SRP)

$$
\begin{aligned}
& =\mathrm{I}-(\mathrm{K}+\mathrm{J}) \\
= & \mathrm{C} /(\mathrm{A}-\mathrm{B}) \\
= & \mathrm{G} /(\mathrm{E}-\mathrm{F}) \\
= & \mathrm{A} / \mathrm{E} \\
= & \mathrm{B} / \mathrm{F} \\
= & (\mathrm{A}-\mathrm{B}) /(\mathrm{E}-\mathrm{F}) \\
= & \mathrm{D} / \mathrm{H} \\
= & \mathrm{L} / \mathrm{E}
\end{aligned}
$$

Table 3: Determination of tradable and nontradable input

\begin{tabular}{ll}
\hline Tradable & Nontradable \\
\hline Urea Fertilazer & Manure \\
\hline SP-36 Fertilazer & Seeds \\
\hline Phonska Fertilazer & Kompos Fertilizer \\
\hline KCI Fertilizer & Petroganik Fertilizer \\
\hline Pesticide & Karbio Fertilizer \\
\hline & Dolomit \\
\hline & KNO3 Fertilizer \\
\hline & Micro Fertilizer \\
\hline & Labour \\
\hline & Land Tax \\
\hline & Equipment \\
\hline & Land \\
\hline & Corncob \\
\hline & Irrigation cost \\
\hline
\end{tabular}

\section{Source: Authors}

The assumption of Rupiah exchange rate was Rp 9,830.26 / US \$ and the shadow exchange rate was Rp 9,826.24 / US \$. Input was divided into two, namely tradable inputs and non-tradable inputs, details explanation in Table 3 . The social price of rice, corn, urea, SP-36, Phonska and $\mathrm{KCl}$ was predicted by price Free On Board (FOB) and the price of Cost, Insurance and Freight (CIF). The social price of pesticides was $80 \%$ of its private price, because the pesticides prices prevailing in the market considered include $20 \%$ import tax of (Oemar and Mulyana, 2006). The social price of labor is calculated at $80 \%$ of its private prices becausefarmers' labor is considered to have lower productivity (Suryana, 1980). The social price of manure, seeds, compost fertilizer,petroganik, dolomite, karbiofertilizer, KNO3 fertilizer, micro fertilizers, equipment depreciation, landlease, corncob, irrigation costs and transport costs similar with private prices, while the tax on social price considered zero because the tax is a form of government intervention that should not exist in a perfectly competitive market. Sensitivity analysis was used to determine the impact of changes in the components of revenues, expenses and profits in the farming of food commodities. Analyzer tools used to measure the sensitivity of PCR is the elasticity of PCR and the DRC, with the following formula:

$P C$ elasticity $=\frac{\Delta P C R / P C R}{\Delta X i / X i}$ 
$D R C$ elasticity $=\frac{\Delta D R C / D R C}{\Delta X i / X i}$

Where;

$\triangle P C R \quad=$ Change of PCR value

$\triangle D R C=$ Change of DRC value

$\Delta X i \quad=$ Change of tested parameter

Xi $\quad=$ Tested parameter

Criteria, If :

PCR or DRC elasticity $<1$ means inelastic

PCR or DRC elasticity $\geq 1$ meanselastic

\section{Result and Discussion}

\section{Competitiveness of strategic food commodities}

Competitiveness of strategic food commodities can be measured by the PCR and the DRC value from the PAM matrix. PCR value indicates a competitive advantage while DRC value shows comparative advantage. PAM matrix of strategic food commodities can be seen in Table 4. Table 4 shows that private profit and social profit of food commodities farming in Lampung province is positive. This means that the strategic food commodities farming in Lampung Province is profitable both financially and economically. Furthermore, components of private revenues, expenses and profits is different from social revenue, cost and profit. The variation in the private and social revenue is due to different rates of output price between private and social. The cause of the variation is the the market structure for rice and corn which are generally oligopsonistic, this is in line with Zakaria (2000) and Zakaria, Lestari, and Indriani (2004).

Table 4: Policy Analysis Matrix of strategic food commodities farming (per hectare) in Lampung Province, 2016/2017

\begin{tabular}{|c|c|c|c|c|c|}
\hline & Components & Revenue & $\begin{array}{l}\text { Tradable } \\
\text { Input }\end{array}$ & $\begin{array}{l}\text { Nontradable } \\
\text { Input }\end{array}$ & Profit \\
\hline & & $(\mathbf{R p})$ & (Rp) & (Rp) & (Rp) \\
\hline \multicolumn{6}{|l|}{ Rice } \\
\hline \multirow[t]{3}{*}{ MT I } & Private price & $19.719 .956,40$ & $1.451 .683,31$ & $13.515 .012,41$ & $4.753 .260,68$ \\
\hline & Social price & $22.002 .582,45$ & $2.522 .670,90$ & $12.615 .144,09$ & $6.864 .767,47$ \\
\hline & Divergence & $-2.282 .626,06$ & $-1.070 .987,59$ & $899.868,32$ & $-2.111 .506,79$ \\
\hline \multirow[t]{3}{*}{ MT II } & Private price & $17.195 .853,88$ & $1.413 .559,20$ & $12.769 .228,56$ & $3.013 .066,12$ \\
\hline & Social price & $16.618 .717,03$ & $2.166 .816,85$ & 11.933.646,19 & $2.518 .254,00$ \\
\hline & Divergence & $577.136,84$ & $-753.257,64$ & $835.582,37$ & $494.812,12$ \\
\hline \multicolumn{6}{|l|}{ Corn } \\
\hline \multirow[t]{3}{*}{ MT I } & Private price & $13.310 .944,59$ & $1.667 .684,36$ & $6.073 .785,10$ & $5.569 .475,13$ \\
\hline & Social price & $16.490 .429,65$ & $2.816 .087,69$ & $5.588 .892,04$ & $8.085 .449,91$ \\
\hline & Divergence & $-3.179 .485,06$ & $-1.148 .403,33$ & $484.893,05$ & $-2.515 .974,79$ \\
\hline \multirow[t]{3}{*}{ MT II } & Private price & $11.904 .379,70$ & $1.626 .920,05$ & $5.989 .764,09$ & $4.287 .695,55$ \\
\hline & Social price & $12.729 .789,57$ & $2.467 .413,77$ & $5.511 .405,22$ & $4.750 .970,57$ \\
\hline & Divergence & $-825.409,87$ & $-840.493,72$ & $478.358,87$ & $-463.275,02$ \\
\hline
\end{tabular}

\section{Source: Authors}

The difference in private inputs cost of tradable and non-tradable caused by the policies set by the government for tradable inputs, such as fertilizer subsidies and pesticides import taxes, as well as the policy on non-tradable inputs such as the minimum wage policy. Market distortion and government policies affect the private and social profit of food commodities. Largest Private and social profit of food commodities per year is gained from corn farming, respectively Rp 9,857,170.68/ha and Rp 12,836,420.49/ha. Competitiveness indicators of strategic food commodities in Lampung isshown in Table 5. 
Table 5: Indicators ofcompetitiveness strategic food commodities in Lampung Province, 2016/2017

\begin{tabular}{lcccc}
\hline Ratio & Rice & & Corn & \\
\hline & MT I & MT II & MT I & MT II \\
\hline $\boldsymbol{P C R}$ & 0,74 & 0,81 & 0,52 & 0,58 \\
\hline $\boldsymbol{D} \boldsymbol{R} \boldsymbol{C}$ & 0,65 & 0,83 & 0,41 & 0,54 \\
\hline
\end{tabular}

Table 5 shows that the strategic food commodities which include rice and maize in Lampung Province have competitiveness both financially and economically, which is characterized by less than one PCR and DRC value. The smaller the value of PCR and the DRC, the higher competitiveness. This is in line with Zakaria, Lestari, and Indriani (2004), the production of rice in two cultivation systems, with irrigation and rainfed, has competitiveness both in the rainy season and dry season. This study is also in line with research of Abidin (2006).

Indicators of government policy can be determined based on the value of output Transfer (OT), Nominal Protection Coefficient of Output (NPCO), Input Transfer (IT), Nominal Protection Coefficient of Input (NPCI), Transfer Factor (FT), Net Transfer (NT), efective Protection Coefficient (EPC), Profitability Coefficient (PC) and Subsidy Ratio to Producers (SRP). Policy indicators for strategic food commodities can be seen in Table 6.

Table 6: Indicators of government policy on strategic food commodities farming in Lampung

\begin{tabular}{lllll}
\hline Ratio & Rice & & Corn & MT II \\
\hline $\boldsymbol{O T}$ & MT I & MT II & MT I & $-825.409,87$ \\
\hline $\boldsymbol{N P C O}$ & $-2.282 .626,06$ & $577.136,84$ & $-3.179 .485,06$ & 0,94 \\
\hline $\boldsymbol{I T}$ & 0,90 & 1,03 & 0,81 & $-840.493,72$ \\
\hline $\boldsymbol{T F}$ & $-1.070 .987,59$ & $-753.257,64$ & $-1.148 .403,33$ & $478.358,87$ \\
\hline $\boldsymbol{N P C I}$ & $899.868,32$ & $835.582,37$ & $484.893,05$ & 0,66 \\
\hline $\boldsymbol{N T}$ & 0,58 & 0,65 & 0,59 & $-463.275,02$ \\
\hline $\boldsymbol{P C}$ & $-2.111 .506,79$ & $494.812,12$ & $-2.515 .974,79$ & 0,90 \\
\hline $\boldsymbol{E P C}$ & 0,69 & 1,20 & 0,69 & 1,00 \\
\hline $\boldsymbol{S R P}$ & 0,94 & 1,09 & 0,85 & $-0,0364$
\end{tabular}

\section{Source: Authors}

OT value is the difference between private revenue and social revenue, whereas NPCO is the ratio between private revenue and social revenue. OT value on rice farming (MT I) and corn are negative and NPCO value is less than one. It shows that revenue of farming that is received by farmers is lower than it expectation because private output price is lower than the social price. One of the reason is oligopsonistic market structure, where there are few buyers (contractors) with many sellers (farmers) so that farmers act as price takers. Different condition occurs in rice farming (MT II) where OT values are positive and NPCO is more than one. This condition happened because the average of rice FOB price at MT II is decrease and tends to be lower than the average price of rice in the area of research so that private revenue is higher than social revenue.

IT value represents the difference between private tradable inputs cost and social tradable input cost, while NPCI is the ratio between private tradable inputs cost with social cost. IT value onstrategic food commodities farm is negative and NPCI is less than one, which means that farmers pay the cost of tradable inputs cheaper than it should be. This is due to subsidies policies which implemented by the government for Urea fertilizer, Phonska and SP-36, as well as import taxes for drugs. Transfer Factor (FT) is the difference between private non-tradable inputs cost with social costs. FT value on strategic food commodities is positive, which means that farmers pay non-tradable inputs cost higher than it should be. This is due to the policy of Average Minimum Wage (UMR). The policy aims to protect workers from low wage. This policy negatively affectsstrategic food commoditiesfarming, due to the transfer of profits from farmers tonon-tradable inputs manufacturers. Net transfer (NT) is the difference between private profits to social profits, while Profitability Coefficient (PC) is the ratio of private profits to social profit. Net transfers show the overall impact of government policy on farming systems of strategic food commodities. NT value on rice farming (MT I) and corn are negative with PC value of less than one. It means that the profit received by farmers is lower than expected, and the government's 
policies, output as well as input policy, have not provide incentives to farmers yet. Different conditions occur in rice farming in MT II where the NT value is positive and PC is more than one, which means that the farmer gains higher profit than it should be. This is because on MT II, very few farmers who grow rice so that the price of private output price is higher than the social price. EPC is the ratio between the difference of private revenue and private tradable input costs and the difference of socialrevenue and private tradable input costs. EPC value in rice farming (MT I) and corn (MT I) are less than one. These conditions indicate that the distortion of the market and government policy towards the input and output still disprotected, existing policy should be able to protect farmers and encourage exports. EPC values in rice farming (MT II) and corn (MT II) are more than one, which means the overall policies of the government provide protection for farmers in production activity

SRP is the ratio between the divergence of the profit components with social revenue. SRP value on rice farming (MT I) and corn are negative, which means that any market distortions and government policy towards the input and output causing a decrease in profit of farmers, while the value of SRP on rice farming (MT II) is positive, which means that market distortions and government policies for the input and output causing an increase in farmer profits.

\section{Sensitivity Analysis}

Sensitivity analysis is used to determine the impact of revenues, cost and profit changes in competitiveness analysis. Two scenarios were used in the sensitivity analysis of strategic food commodities, namely the increase in the increase in fertilizer costs and a decrease in output prices.

\section{The Increase of fertilizer cost}

Sensitivity analysis of the increase in fertilizer price was done by rising the price of fertilizer to make PCR value equal to one, which means that the competitive advantage is at break-even point. The results of the sensitivity analysis of the increase of fertilizer price increases seen in Table 7.

Table 7: Sensitivity Analysis of the Increase in FertilizerPrice

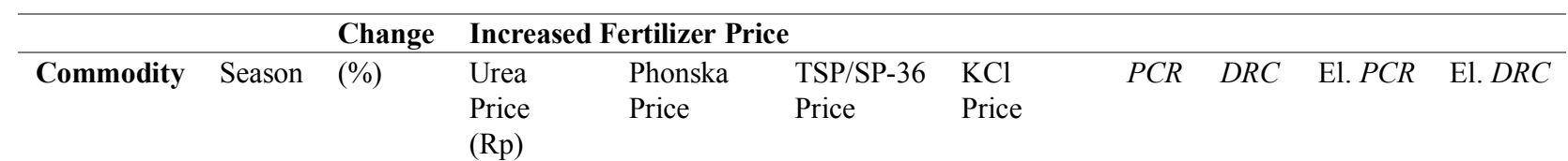

\begin{tabular}{llllllllllll}
\hline Rice & MT I & $417,3 \%$ & $9.819,93$ & $12.913,34$ & $11.630,33$ & $28.404,47$ & 1,00 & 1,26 & 0,08 & 0,22 & 0,08 \\
\hline & MT II & $273,5 \%$ & $7.147,76$ & $9.265,98$ & $8.188,27$ & $19.870,20$ & 1,00 & 1,29 & 0,08 & 0,21 & \\
\hline Corn & MT I & $425 \%$ & $10.333,45$ & $13.984,09$ & $12.661,25$ & $29.100,00$ & 1,00 & 1,90 & 0,21 & 0,86 & \\
\hline & MT II & $336 \%$ & $8.581,68$ & $11.610,52$ & $10.460,21$ & $24.166,86$ & 1,00 & 1,88 & 0,21 & 0,74 &
\end{tabular}

Source: Authors

Fertilizer is a very important input component for farmers. Therefore, the government set the fertilizer subsidy policy so the price becomes cheaper and can be reached by all the farmers. Based on the sensitivity analysis, the increase in the price of fertilizer in rice farming are 417.3 percent (MT I) and 273.5 percent (MT II), corn are 425 percent (MT I) and 336 percent (MT II) those values make the PCR and DRC value equal to one. This shows that the competitive and comparative advantage is at breakeven point.

\section{The Decrease in output price}

Sensitivity analysis of the decrease in output price was done by lowering the price of output to create equal to one PCR value, which means that the competitive advantage is at break-even point. The results of the sensitivity analysis of the decrease in output prices shown in Table 8.

Table 8: Sensitivity Analysis of the Decrease in OutputPrice

\begin{tabular}{lllllllll}
\hline \multicolumn{10}{c}{ \% Decrease Output Price } \\
\hline \multirow{2}{*}{ Rice } & & Private Cost (Rp/kg) & Social Cost (Rp/kg) & $P C R$ & $D R C$ & El. $P C R$ & El. $D R C$ \\
\hline \multirow{2}{*}{ Corn } & MT I & $24 \%$ & $2.686,60$ & $2.997,58$ & 1,00 & 0,89 & 1,46 & 1,55 \\
\hline & MT II & $17,15 \%$ & $3.012,87$ & $2.911,75$ & 1,00 & 1,03 & 1,34 & 1,43 \\
\hline & MT I & $42 \%$ & $1.080,93$ & $1.339,13$ & 1,00 & 0,82 & 2,81 & 2,42 \\
\hline
\end{tabular}

\section{Source: Authors}

The analysis showed that the competitive advantage of rice farming (MT I and MT II) and corn (MT I and MT II) will be at break even if the decline in the price of each output are 24 percent, 17.15 percent, 42 percent, and 36 percent. PCR elasticity and DRC 
value which are higher than one indicates that the competitiveness of strategic food commodities sensitive to a decrease in output prices.

\section{Policy instrument}

The sensitivity analysis showed that the increase in fertilizer cost and the decrease in output price cause a decrease in competitiveness of rice and corn farming. PCR elasticity and the DRC value showed that the competitiveness of rice and corn are not sensitive to the increase in fertilizer costs but sensitive to a decrease in output price. It means that the stability of the price of rice and corn is very important to be maintained. Therefore output minimum price policy for those commodities is needed in order to improve its competitiveness. Output price is a very important variable in determining the competitiveness of strategic food commodities. Competitiveness of strategic food commodities which are most vulnerable to the decrease in output prices is the competitiveness of rice. A decrease in output price with a low percentage makes rice farming lose competitiveness. A decrease in output price will also affect profits that was received by farmers. Therefore the condition might trigger land conversion, from paddy fields to corn farming.

The profit of paddy farming is Rp 7,766,326.79 per hectare per year. That amount of profit is lower than corn farming profits with the amount of USD 9,857,170.68 per hectare per year. That condition might lead to land conversion, from rice to corn farm. Therefore, we need output price policies that can regulate rice grain price to remain stable in order to provide higherprofit than corn farming profits. Assuming that the private price of corn has not changed (fixed), ie USD $1852.50 / \mathrm{kg}$ (MT I) and USD $1944.17 / \mathrm{kg}$ (MT II), the analysis shows that the price of rice grain which provide higher profit per year compare to corn farming profits is $\$ 3850.00 / \mathrm{kg}$ (Table 9).

Table 9: PAM of Rice and Corn Farming

\begin{tabular}{llllll}
\hline & Components & Revenue & tradable Input & nontradable Input & Profit \\
\hline Rice (Rp 3.850/kg) & & & & & \\
\hline - MT I & Private price & $21.477 .180,23$ & $1.451 .683,31$ & $13.515 .012,41$ & $6.510 .484,51$ \\
\hline & Social price & $22.002 .582,45$ & $2.522 .670,90$ & $12.615 .144,09$ & $6.864 .767,47$ \\
\hline & Divergence & $-525.402,22$ & $-1.070 .987,59$ & $899.868,32$ & $-354.282,95$ \\
\hline - MT II & Private price & $18.205 .235,04$ & $1.413 .559,20$ & $12.769 .228,56$ & $4.022 .447,28$ \\
\hline & Social price & $16.618 .717,03$ & $2.166 .816,85$ & $11.933 .646,19$ & $2.518 .254,00$ \\
\hline Corn & Divergence & $1.586 .518,01$ & $-753.257,64$ & $835.582,37$ & $1.504 .193,28$ \\
\hline - MT I & & & & \\
\hline & Private price & $13.310 .944,59$ & $1.667 .684,36$ & $6.073 .785,10$ & $5.569 .475,13$ \\
\hline & Social price & $16.490 .429,65$ & $2.816 .087,69$ & $5.588 .892,04$ & $8.085 .449,91$ \\
\hline - MT II & Divergence & $-3.179 .485,06$ & $-1.148 .403,33$ & $484.893,05$ & $-2.515 .974,79$ \\
\hline & Private price & $11.904 .379,70$ & $1.626 .920,05$ & $5.989 .764,09$ & $4.287 .695,55$ \\
\hline & Social price & $12.729 .789,57$ & $2.467 .413,77$ & $5.511 .405,22$ & $4.750 .970,57$ \\
\hline
\end{tabular}

Source: Authors

The rice grain price is two times higher than the price of corn at the farmer level. Thus, to prevent land conversion, the government set the price of grain twice the price of corn, which is stated in the grain minimum price policy. Besides rice, the competitiveness of strategic food commodities which are also sensitive to a decrease in output prices is competitiveness of corn. Government intervention to stabilize the price of corn through the implementation of regional Minimum Price policy (HMR) is needed to anticipate these conditions.

\section{Conclusions}

Food commodities play an important role in income increase of people, job opportunities, and regional and national development. Competitiveness of food commodities needs for community welfare increase and national food security and sovereignty. In this study, it was aimed (1) to analysis of competitiveness of strategic food commodities in Lampung Province, (2) to analyze the impact of changes of input and output prices against of strategic food commodities in Lampung Province, and (3) to know the policy of suitable minimum prices of strategic food commodities in Lampung Province. . This research conducted in Lampung Province from September 2013 to September 2014. The regencies as a sample selected by purposive sampling were Middle Lampung, North Lampung, South Lampung, and East Lampung. Based on the research that has been conducted, it is concluded that the strategic food commodities farm in Lampung Province are financially and economically competitive with PCR and DRC value less than one. Competitiveness of strategic food commodities in Lampung decrease with the increase in fertilizer cost also the decrease in output prices. Competitiveness of strategic food commodities in Lampung is sensitive to a decrease in output prices. Regional minimum price policy for strategic food commodities (rice and corn) is necessary to prevent land conversion between the commodities. The minimum price of rice (grain) is twice the price of corn. The results showed that the farming of strategic food commodities (paddy and corn) had PCR and DCR value less than one point. Strategic food commodities had lesser value due to an increase in fertilizer price and a decline in output prices. The competitiveness of strategic food commodities in Lampung Province was sensitive to output prices decrease. The policy of the minimum price of paddy at least two times greater than the price of corn. 


\section{References}

Abidin, Z. (2007). Daya Saing Usahatani Ubi Kayu untuk Biofuel di Lahan Kering Kabupaten Lampung Tengah. Journal of SosioEkonomika 14 (1), 47-61.

Badan Pusat Statistik. (2013). Statistik Indonesia 2013. Bandar Lampung: BPS Provinsi Lampung

Kementerian pertanian. (2009). Rancangan Rencana Strategis Kementerian Pertanian Tahun 2010-2014. Departemen Pertanian, Jakarta.

Oemar, A. dan A. Mulyana. (2006). Daya Saing Usaha Perkebunan Kelapa Sawit di Sumatera Selatan sebagai Subsektor yang Diintervensi Pemerintah.Journal of SosioEkonomika 12 (1), 44-52.

Pearson, S., Gotsch, C., \&Bahri, S..(2005). Aplikasi Policy Analisys Matrix pada Pertanian Indonesia. Jakarta: Yayasan Obor Indonesia.

Sambodo, M.T., Ahmad H. F., Latif A., Purwanto. (2007). Mengurai Benang Kusut Daya Saing Indonesia. Jakarta: LIPI Press.

Suryana, A. (1980). Keuntungan Komparatif Dalam Produksi Ubikayu dan Jagung di JawaTimur dan Lampung Dengan Analisa Penghematan Biaya Sumberdaya Domestik. Tesis. Bogor: Institut Pertanian Bogor.

Zakaria, W.A. (2000). Analisis Permintaan dan Penawaran Ubi Kayu di Propinsi Lampung. Disertasi. Institut Pertanian Bogor, Bogor.

Zakaria, WA; Lestari, DAH.;and Indriani, Y. 2004. The Impact of Irrigation on Rice Production in Lampung Province. University of Lampung, Bandar Lampung 